OPEN ACCESS

Edited by:

Fushun Wang,

Nanjing University of Chinese Medicine, China

Reviewed by:

Chengqi $X u$,

Huazhong University of Science and Technology, China

Yihong M. A.,

Kumamoto University, Japan

*Correspondence:

Songbai Xu

xusongbai@jlu.edu.cn

Bingjin Li

libingjin@jlu.edu.cn

Specialty section:

This article was submitted to Behavioral and Psychiatric Genetics,

a section of the journal

Frontiers in Genetics

Received: 15 May 2020

Accepted: 01 September 2020

Published: 15 October 2020

Citation:

Zhao L, Han G, Zhao Y, Jin Y, Ge T, Yang W, Cui R, Xu S and Li B (2020) Gender Differences

in Depression: Evidence From Genetics. Front. Genet. 11:562316. doi: 10.3389/fgene.2020.562316

\section{Gender Differences in Depression: Evidence From Genetics}

\author{
Lihong Zhao', Guanghong Han'2, Yinghao Zhao', Yang Jin', Tongtong Ge', Wei Yang', \\ Ranji Cui', Songbai $\mathrm{Xu}^{3 *}$ and Bingjin $\mathrm{Li}^{1 *}$
}

1 Jilin Provincial Key Laboratory on Molecular and Chemical Genetics, Second Hospital of Jilin University, Changchun, China, ${ }^{2}$ Department of Oral Geriatrics, Hospital of Stomatology, Jilin University, Changchun, China, ${ }^{3}$ Department of Neurosurgery,

First Hospital of Jilin University, Changchun, China

Compared with men, female accounts for a larger proportion of patients with depression. Behavioral genetics researches find gender differences in genetic underpinnings of depression. We found that gender differences exist in heritability and the gene associated with depression after reviewing relevant research. Both genes and gene-environment interactions contribute to the risk of depression in a gender-specific manner. We detailed the relationships between serotonin transporter gene-linked promoter region (5-HTTLPR) and depression. However, the results of these studies are very different. We explored the reasons for the contradictory conclusions and provided some suggestions for future research on the gender differences in genetic underpinnings of depression.

Keywords: depression, gender difference, genetics, gene-environment interactions, heritability

\section{INTRODUCTION}

Depression is a prevalent mental illness that seriously affects physical and mental health (Krishnan and Nestler, 2008; Ge et al., 2018; Ren et al., 2020). Women are more likely to suffer from depression (Young et al., 1990; Harkness et al., 2010; Wang et al., 2019). The susceptibility to depression is affected by diverse hereditary, epigenetic, environmental, and endocrine risk factors (Duman et al., 2016). With the rise of developmental behavioral genetics (using the research methods and techniques of psychology and behavioral genetics to examine the influence of genetics and environment on the development of human psychology and behavior), more and more researchers began to pay attention to the role of genetic factors in the occurrence of gender differences in depression. Behavioral genetics research methods include quantitative genetics (mainly through twins and adoption research to find evidence that genetics and the environment affect human psychology and behavior) and molecular genetics [identify susceptibility genes associated with specific psychology and behavior, including candidate gene association studies and genome-wide association studies (GWAS)]. Twin studies show differences in the heritability of depression between men and women, and molecular genetics studies show gender differences in depression caused by specific genes and their interaction with the environment. However, these findings are not consistent.

This manuscript reviews relevant studies on the genetic underpinnings of gender differences in depression. Besides, we explored the reasons for the contradictory conclusions and provided some suggestions for future research on the genetic underpinnings of gender differences in the depression. We hope this manuscript will help scientists better understand and study genetic underpinnings of gender differences in the depression. 


\section{EPIDEMIOLOGY}

Many national and international studies display that sex ratio (women: men) of depressive disorders over 1.7 for lifetime prevalence and 1.4 for 12-month prevalence after the age of 18 (Kuehner, 2017). The gender difference in depression rates first emerge in adolescence and continues into old age (Angold and Worthman, 1993), although the gender gap of the adult is smaller than it is at younger ages (Patten et al., 2016; Kiely et al., 2019). Similar gender differences exist in different income countries, although significant cross-national variation exists (Van de Velde et al., 2010). But, gender differences do not exist across all race-ethnic groups (Kessler, 2003; Yancu, 2011). The female predominate in the incidence of depressive disorders; instead, there appears to be no gender difference in recurrence, remission, or chronicity of depression (Kessler, 2003; Otte et al., 2016). The symptom profile of men and women with depression is different. Women are more likely to show increased appetite, hypersomnia, somatic symptoms, etc. (Piepenburg et al., 2019). Especially, comorbidity of peripartum depression with anxiety disorders, obsessive-compulsive disorder, and post-traumatic stress disorder worth attention (Kuehner, 2017).

\section{GENDER DIFFERENCES IN HERITABILITY}

The family pedigree study finds depression is hereditary. According to reports, children of depressed parents have increased symptoms of depression and internalization (Rice et al., 2002). Later, the twin study divided the sources of phenotypic variation of depression into three aspects: genetic, shared environment, and non-shared environment, which provided the possibility of separating the role of genetic and environmental.

Most Scholars use the twin paradigm in quantitative genetics to investigate gender differences in the genetic basis of depressive symptoms. Research on gender differences in heritability of depressive symptoms mainly focuses on adolescents in European and American countries. Adolescence is a particularly good time when many people will experience the first onset (Eley et al., 2004). During adolescence, the prevalence rate of depression in men and women has begun to rise dramatically, especially in girls. Similarly, the heritability of depression increased from childhood to adolescents (Ksinan and Vazsonyi, 2019). Biological and pubertal changes, cognitive maturity occurs during adolescence, some genetic factors may be "switched on" to promote these changes, which in turn affect depressive symptoms (Lau and Eley, 2006). Jacobson and Rowe (1999) show that the heritability in depressed mood is higher in female adolescents than in male adolescents (self-rated depressive symptoms), however, Rice et al. (2002) shows the opposite result (self-rated depressive symptoms). McCaffery et al. (2008) reported that non-shared environment and the genetic factors contribute to the correlation of depressive symptoms in female adolescents and cigarette smoking; but In male adolescents, only non-shared environment. In an older twin study, the heritability of women was also higher than that of men, although no statistically significant (Jansson et al., 2004). Scourfield et al. (2003) show higher heritability for young girls (children) than young boys only from parent-rated depressive symptoms, not self-rated depressive symptoms. Some methodological differences exist in these surveys, including measurement methods, source of information (informant), the age range of the sample, number of samples, sibling-pairs sample, demographic characteristics (Table 1), which limits comparability between surveys. We are not sure whether the difference in the heritability of depressive symptoms exists between gender.

Several reasons can explain the divergence of the above conclusions. First, the genetic factors on depressive symptom vary according to the individual's developmental stage (such as childhood and adolescence) or age: Both self-reports and parent reports show that individuals with early adolescence have a higher heritability in depressed mood than individuals with mid-adolescence (Hou et al., 2012); genetic factors become more important from childhood to adolescence or less important (Rice et al., 2002; Scourfield et al., 2003). Most studies have analyzed adolescents at different developmental stages of adolescence and may have overlooked the change in genetic interpretation of depressive symptoms during adolescence. Like most complex behaviors, depression does not simply follow Mendel's single gene inheritance law but is affected by multiple genes, known as quantitative trait locus (QTL). Different genes are turned on in different time, the interaction between genes and the interaction between genes and the environment show different patterns at different stages of development, so the influence of genetics and environment on adolescents' depression is dynamically changing (Hou et al., 2012). Second, The inheritance rate varies according to the reporter and genetic influences may be less important for child-rated depression symptoms than for parent-rated symptoms (Rice et al., 2002): Proxy ratings can be influenced by the informant's symptoms of depression and anxiety; Self-reports and parental reports may have evaluated different aspects of depressive symptom or depressive symptom at different moments; in parents-report, parents need to rate two twins. In this process, two twins will be inevitably compared with each other, or the two children will be rated more similarly, or the rating will be less similar. In self-reporting, a child only needs to report themselves' emotional experience. Third, the small number of subjects may not be sufficient to produce convincing results. Modest heritability (30-40\%) (Sullivan et al., 2000), clinical heterogeneity and complicated genetic architecture for major depression requires a larger sample size. In order to generate replicable and statistically significant findings, 75,000-100,000 major depressive disorder cases are needed in GWAS to identify gene loci involved major depressive disorder (Duman et al., 2016). Also, maximizing sample sizes is more informative to understand genetic heterogeneity of depression (Hall et al., 2018).

\section{GENDER DIFFERENCES IN THE GENE ASSOCIATED WITH DEPRESSION}

The twin studies found that the genetic factor affect depressive symptom of adolescents but gender difference in heritability of depressive symptom remains to be further studied. Molecular 
TABLE 1 | Gender differences in heritability.

\begin{tabular}{|c|c|c|c|c|c|c|c|c|}
\hline Sibling-Pairs Sample & Age Group & Methodology & $\begin{array}{l}\text { Measurement } \\
\text { instruments }\end{array}$ & $\begin{array}{l}\text { Demographic } \\
\text { Characteristics }\end{array}$ & Gender composition & Result & $\begin{array}{l}\text { Source of } \\
\text { information } \\
\text { (informant) }\end{array}$ & References \\
\hline 2,302 pairs Sibling-Pairs & $\begin{array}{l}16 \text { years } \\
\text { (range }=11- \\
20 \text { years) }\end{array}$ & $\begin{array}{l}\text { Cross-sectional } \\
\text { Study }\end{array}$ & $\begin{array}{l}\text { Depressed mood: } \\
\text { Center for } \\
\text { Epidemiological } \\
\text { Studies-Depression } \\
\text { (CES-D) }\end{array}$ & $\begin{array}{l}\text { Caucasian, African } \\
\text { American, other } \\
\text { Ethnicity (A smaller } \\
\text { percentage) }\end{array}$ & $\begin{array}{l}\text { Female: 2285, Male: } \\
2319\end{array}$ & $\begin{array}{l}\text { Heritability in depressed } \\
\text { mood is higher in } \\
\text { female adolescents } \\
\text { than in male } \\
\text { adolescents. Genetic } \\
\text { factors were higher for } \\
\text { female adolescents } \\
\text { than male adolescent in } \\
\text { correlations between } \\
\text { family and school } \\
\text { environment and } \\
\text { adolescent depressed } \\
\text { mood }\end{array}$ & Self-report & $\begin{array}{l}\text { Jacobson and } \\
\text { Rowe, } 1999\end{array}$ \\
\hline $\begin{array}{l}959 \text { twin pairs (123 female MZs, } 90 \\
\text { male MZs, } 207 \text { same-sex female DZs, } \\
109 \text { same-sex male DZs, and } 430 \\
\text { opposite-sex DZs) }\end{array}$ & $\begin{array}{l}50 \text { years or older } \\
\text { (mean age } \\
72 \text { years) }\end{array}$ & $\begin{array}{l}\text { Cross-sectional } \\
\text { Study }\end{array}$ & $\begin{array}{l}\text { Depressive symptoms: } \\
\text { Center for } \\
\text { Epidemiological } \\
\text { Studies-Depression } \\
\text { (CES-D) and } \\
\text { self-reported use of } \\
\text { antidepressant } \\
\text { medication. }\end{array}$ & Caucasians & $\begin{array}{l}\text { Female: 1090, Male: } \\
828\end{array}$ & $\begin{array}{l}\text { Higher heritability for } \\
\text { women than men (no } \\
\text { statistically significant). }\end{array}$ & Self-report & $\begin{array}{l}\text { Jansson et al., } \\
2004\end{array}$ \\
\hline $\begin{array}{l}287 \mathrm{MZ} \text { (143 male-male, } 144 \\
\text { female-female pairs) and } 441 \mathrm{DZ} \text { twin } \\
\text { pairs ( } 132 \text { male-male, } 113 \\
\text { female-female, and } 196 \text { male-female) }\end{array}$ & $\begin{array}{l}\text { Mean age } \\
16.1 \text { years }\end{array}$ & $\begin{array}{l}\text { Cross-sectional } \\
\text { Study }\end{array}$ & $\begin{array}{l}\text { Depressive symptoms. } \\
\text { Center for } \\
\text { Epidemiologic } \\
\text { Studies-Depression } \\
\text { Scale (CES-D) }\end{array}$ & $\begin{array}{l}\text { Caucasian, African } \\
\text { American, } \\
\text { Hispanic/Latino other } \\
\text { ethnicities (A smaller } \\
\text { percentage) }\end{array}$ & Female: 710 , Male: 746 & $\begin{array}{l}\text { In female, non-shared } \\
\text { environment and } \\
\text { genetic factors } \\
\text { contribute to the } \\
\text { correlation of } \\
\text { depressive symptoms } \\
\text { and cigarette smoking. } \\
\text { In male, only } \\
\text { non-shared } \\
\text { environment. }\end{array}$ & Self-report & $\begin{array}{l}\text { McCaffery } \\
\text { et al., } 2008\end{array}$ \\
\hline 670 twin pairs (MZ and DZ) & $5-17$ years & $\begin{array}{l}\text { Cross-sectional } \\
\text { analyses } \\
\text { longitudinal study }\end{array}$ & $\begin{array}{l}\text { Depressive symptoms: } \\
\text { Parent and self-report } \\
\text { questionnaire data } \\
\text { Mood and Feelings } \\
\text { Questionnaire. }\end{array}$ & Wales & Female: 636, Male: 612 & $\begin{array}{l}\text { Only parent-report data } \\
\text { show that girls show } \\
\text { greater genetic effects } \\
\text { than boys. }\end{array}$ & Self-report & $\begin{array}{l}\text { Scourfield } \\
\text { et al., } 2003\end{array}$ \\
\hline 1463 families & $8-17$ years & $\begin{array}{l}\text { Cross-sectional } \\
\text { analyses }\end{array}$ & $\begin{array}{l}\text { Depressive symptoms: } \\
\text { Mood and Feelings } \\
\text { Questionnaire and } \\
\text { Hospital Anxiety and } \\
\text { Depression Scale }\end{array}$ & $\begin{array}{l}\text { South Wales and } \\
\text { Greater Manchester }\end{array}$ & & $\begin{array}{l}\text { For self-rated } \\
\text { depressive symptoms, } \\
\text { adolescents ( } 11 \text { years } \\
\text { and over) show greater } \\
\text { genetic effects than } \\
\text { female }\end{array}$ & $\begin{array}{l}\text { Self-rated } \\
\text { parent-rated }\end{array}$ & $\begin{array}{l}\text { Rice et al., } \\
2002\end{array}$ \\
\hline $508 \mathrm{MZ}, 176 \mathrm{DZ}$ & $10-19$ years & Longitudinal study & $\begin{array}{l}\text { Depressive symptoms: } \\
\text { Children's Depression } \\
\text { Inventory, CDI }\end{array}$ & Chinese & & $\begin{array}{l}\text { No gender difference in } \\
\text { the heritability of } \\
\text { adolescent Depressive } \\
\text { symptoms }\end{array}$ & $\begin{array}{l}\text { Self-rated } \\
\text { parent-rated }\end{array}$ & $\begin{array}{l}\text { Hou et al., } \\
2012\end{array}$ \\
\hline
\end{tabular}


TABLE 2 | 5-HTTLPR alone and interaction with the environment contribute to the risk of depression.

\begin{tabular}{|c|c|c|c|c|c|c|c|c|c|}
\hline Age & Gene & $\begin{array}{l}\text { Measurement } \\
\text { instruments }\end{array}$ & $\begin{array}{l}\text { Environmental } \\
\text { factor }\end{array}$ & $\begin{array}{l}\text { Gender } \\
\text { composition }\end{array}$ & $\begin{array}{l}\text { Demographic } \\
\text { Characteristics }\end{array}$ & $\begin{array}{l}\text { Source of } \\
\text { information } \\
\text { (informant) }\end{array}$ & Study Design & Result & References \\
\hline $\begin{array}{l}337 \\
\text { adolescents } \\
\text { aged } \\
10-20 \text { years }\end{array}$ & $\begin{array}{l}\text { 5-HTTLPR (L/S), } \\
\text { HTR2A, HTR2C, } \\
\text { MAOA (monoamine } \\
\text { oxidase type A) and } \\
\text { tryptophan } \\
\text { hydroxylase (TPH) }\end{array}$ & $\begin{array}{l}\text { Short form of Mood and } \\
\text { Feelings Questionnaire } \\
\text { (SMFQ) }\end{array}$ & $\begin{array}{l}\text { Family } \\
\text { environmental risk: } \\
\text { family social } \\
\text { adversity; parental } \\
\text { educational level; } \\
\text { adverse life events }\end{array}$ & $\begin{array}{l}\text { Female: } 220, \\
\text { Male: } 117\end{array}$ & & $\begin{array}{l}\text { Self-report } \\
\text { questionnaire }\end{array}$ & $\begin{array}{l}\text { Cross-sectional } \\
\text { Study }\end{array}$ & $\begin{array}{l}\text { 1. The main effect of } 5 \text { HTLPR "short" } \\
\text { alleles was significant only in the } \\
\text { female. an overall decrease in odds of } \\
\text { depression for an increasing number of } \\
\text { "short" alleles. } \\
\text { 2. 5-HTTPLR "short-short" genotype } \\
\text { interacts with high environmental risk } \\
\text { increase depression risk only for female }\end{array}$ & Eley et al., 2004 \\
\hline $16-19$ years & 5-HTTLPR (L/S) & $\begin{array}{l}\text { [Depression Self-Rating } 1 \\
\text { Scale (DSRS)] of the } \\
\text { DSM-IV }\end{array}$ & $\begin{array}{l}\text { 1. Type of residence } \\
\text { 2. Separated } \\
\text { families' } \\
\text { 3. Traumatic conflicts } \\
\text { within the family }\end{array}$ & $\begin{array}{l}\text { Female: } 11, \\
\text { Male: } 81\end{array}$ & Swede & $\begin{array}{l}\text { Self-reports } \\
\text { interview }\end{array}$ & $\begin{array}{l}\text { Cross-sectional } \\
\text { Study }\end{array}$ & $\begin{array}{l}\text { 1. Boys and girls carrying the short } \\
5 \text {-HTTLPR allele react to different kinds } \\
\text { of environmental factors. } \\
\text { 2. Females rather than male carrying the } \\
\text { short } 5 \text {-HTTLPR allele tended to } \\
\text { develop depressive symptoms with the } \\
\text { environmental stress factor }\end{array}$ & $\begin{array}{l}\text { Sjöberg et al., } \\
2006\end{array}$ \\
\hline $\begin{array}{l}\text { Study } 1288 \\
\text { participants } \\
\text { mean age } 58.3 \\
\text { Study } 2142 \\
\text { participants } \\
\text { Mean age } 34.0\end{array}$ & 5-HTTLPR (L/S) & $\begin{array}{l}\text { Study } 1 \text { depressive } \\
\text { symptomatology: } \\
\text { Center for Epidemiologic } \\
\text { Studies Depression } \\
\text { Scale (CES-D) Study } 2 \\
\text { depressive symptoms: } \\
\text { The } 40 \text {-item Obvious } \\
\text { Depression scale (OBD) }\end{array}$ & $\begin{array}{l}\text { Study } 1 \text { the } \\
\text { stressor of } \\
\text { c caregiving status } \\
\text { Study } 2 \text { childhood } \\
\text { socioeconomic } \\
\text { status (SES) }\end{array}$ & $\begin{array}{l}\text { Study } 1215 \\
\text { females Study } \\
264 \text { females }\end{array}$ & $\begin{array}{l}\text { Study } 170.5 \% \\
\text { Caucasians Study } \\
247.2 \% \\
\text { Caucasians }\end{array}$ & $\begin{array}{l}\text { Study } 1 \text { home visit } \\
\text { self-reports. Study } \\
2 \text { self-reports. }\end{array}$ & $\begin{array}{l}\text { Cross-sectional } \\
\text { Study }\end{array}$ & $\begin{array}{l}\text { 1. For females, the s allele, combined } \\
\text { with caregiving stress (Study 1) or low } \\
\text { childhood SES (Study 2), was } \\
\text { associated with higher depression } \\
\text { scores as compared to participants in } \\
\text { the non-stressor group and those with } \\
\text { the long (I) allele. } \\
\text { 2. In males, the I allele, combined with a } \\
\text { stressor, was associated with higher } \\
\text { depression scores as compared to } \\
\text { those in the non-stressor group and } \\
\text { those with the s allele }\end{array}$ & $\begin{array}{l}\text { Brummett } \\
\text { et al., } 2008\end{array}$ \\
\hline $\begin{array}{l}\text { Between the } \\
\text { ages of } 22 \text { and } \\
26(n=4724)\end{array}$ & 5-HTTLPR (L/S) & $\begin{array}{l}\text { Depression: using } \\
\text { responses from two } \\
\text { questions; depression } \\
\text { symptoms (CES-D) }\end{array}$ & $\begin{array}{l}\text { 1. Stressful life events } \\
\text { 2. Childhood } \\
\text { maltreatment. }\end{array}$ & $\begin{array}{l}\text { Male } n=2312, \\
\text { Female } \\
n=2412\end{array}$ & $\begin{array}{l}\text { Non-Hispanic } \\
\text { white }\end{array}$ & self-reported & $\begin{array}{l}\text { Cross-sectional } \\
\text { Study }\end{array}$ & $\begin{array}{l}\text { 1. 5-HTTLPR plays a role in moderating } \\
\text { the impact of SLEs on depression } \\
\text { status, a statistically significant only in } \\
\text { males (for SS genotype). } \\
\text { 2. For females carrying one or more of } \\
\text { the S-alleles, the prevalence of suicide } \\
\text { ideation increased with an increasing } \\
\text { number of stressful life events. } \\
\text { whereas, for males, the prevalence } \\
\text { rates increased for carrying one or } \\
\text { more L-alleles }\end{array}$ & $\begin{array}{l}\text { Haberstick } \\
\text { et al., } 2016\end{array}$ \\
\hline $\begin{array}{l}\text { Students } \\
17-18 \text { years }\end{array}$ & 5HTTLPR (L/S) & $\begin{array}{l}\text { Self-rating scale (DSRS) } \\
\text { of the DSM-IV }\end{array}$ & Maltreatment & $\begin{array}{l}\text { Male } n=765 \\
\text { Female } n=717\end{array}$ & $\begin{array}{l}\text { Scandinavian } \\
1245 \text { Non- } \\
\text { Scandinavian } \\
217\end{array}$ & self-reported & $\begin{array}{l}\text { Cross-sectional } \\
\text { Study }\end{array}$ & $\begin{array}{l}\text { A significant main effect and a } G \times E \\
\text { interaction effect of the } S S \text { allele was } \\
\text { found only among girls. }\end{array}$ & $\begin{array}{l}\text { Aslund et al., } \\
2009\end{array}$ \\
\hline
\end{tabular}


TABLE 2 | Continued

\begin{tabular}{|c|c|c|c|c|c|c|c|c|c|}
\hline Age & Gene & $\begin{array}{l}\text { Measurement } \\
\text { instruments }\end{array}$ & Environmental factor & $\begin{array}{l}\text { Gender } \\
\text { composition }\end{array}$ & $\begin{array}{l}\text { Demographic } \\
\text { Characteristics }\end{array}$ & $\begin{array}{l}\text { Source of } \\
\text { information } \\
\text { (informant) }\end{array}$ & Study Design & Result & References \\
\hline $\begin{array}{l}346 \text { youth } \\
\text { mean age } \\
23.7 \text { years }\end{array}$ & 5HTTLPR (L/S) & $\begin{array}{l}\text { Depressive symptoms: } \\
\text { Beck Depression } \\
\text { Inventory-\| }\end{array}$ & $\begin{array}{l}\text { Negative acute life } \\
\text { events } \\
\text { Chronic family stress }\end{array}$ & $\begin{array}{l}132 \text { males, } 214 \\
\text { females }\end{array}$ & 93\% Caucasian & $\begin{array}{l}\text { Interview } \\
\text { measures }\end{array}$ & $\begin{array}{l}\text { Longitudinal } \\
\text { Study }\end{array}$ & $\begin{array}{l}\text { A significant interaction between family } \\
\text { discord and genotype only among } \\
\text { females. The effect of family discord on } \\
\text { BDI was stronger in SL and SS females } \\
\text { compared to LL females }\end{array}$ & $\begin{array}{l}\text { Hammen et al., } \\
2010\end{array}$ \\
\hline $\begin{array}{l}\text { In males: } \\
\text { 12-19 years; In } \\
\text { females: } \\
\text { 12-20 years }\end{array}$ & 5-HTTLPR (L/S) & $\begin{array}{l}\text { Depressive symptom: } \\
\text { Epidemiological Studies } \\
\text { Depression Scale } \\
\text { (CES-D) }\end{array}$ & $\begin{array}{l}\text { Family structure } \\
\text { Family-level } \\
\text { socioeconomic status } \\
\text { (SES) } \\
\text { Social support } \\
\text { County-level } \\
\text { environment }\end{array}$ & $\begin{array}{l}\text { Females } \\
(n=560), \\
\text { Males }(n=524)\end{array}$ & $\begin{array}{l}\text { White (reference), } \\
\text { African-American, } \\
\text { Hispanic, Asian, } \\
\text { and other race }\end{array}$ & $\begin{array}{l}\text { In-home } \\
\text { interview } \\
\text { self-report }\end{array}$ & $\begin{array}{l}\text { Longitudinal } \\
\text { Study }\end{array}$ & $\begin{array}{l}\text { 1. Among females, the main effects } \\
\text { models showed an association } \\
\text { between the SL genotype and lowered } \\
\text { risk of depressive symptoms. } \\
\text { 2. Among males, interaction models } \\
\text { showed an association between } S L \\
\text { genotype and lowered risk of } \\
\text { depressive symptoms in deprived } \\
\text { counties only }\end{array}$ & $\begin{array}{l}\text { Uddin et al., } \\
2010\end{array}$ \\
\hline \multirow[t]{2}{*}{$\begin{array}{l}12-19 \text { years, } \\
\text { males; } \\
12-20 \text { years, } \\
\text { females }\end{array}$} & 5-HTTLPR (L/S) & $\begin{array}{l}\text { Depressive Symptom: } 1 \\
17 \text {-item version of the } \\
\text { Center for } \\
\text { Epidemiological Studies } \\
\text { Depression (CESD) }\end{array}$ & $\begin{array}{l}\text { 1. Respondent-level } \\
\text { building conditions } \\
\text { 2. Neighborhood-level } \\
\text { building conditions }\end{array}$ & $\begin{array}{l}\text { 1. Male } \\
(n=510) \\
\text { Female } \\
(n=574) \\
\text { 2. Male } \\
(n=377) \text { and } \\
\text { Female } \\
(n=418)\end{array}$ & $\begin{array}{l}\text { White (reference), } \\
\text { African American, } \\
\text { Hispanic, Asian, } \\
\text { and other races. }\end{array}$ & Self-reported & $\begin{array}{l}\text { Cross-sectional } \\
\text { Study }\end{array}$ & $\begin{array}{l}\text { 1. No gene-social environment } \\
\text { interaction effects } \\
\text { 2. Respondent-level building analyses } \\
\text { provided some evidence for genetic } \\
\text { influences on depressive symptom } \\
\text { score in adolescent females } \\
\text { 3. Neighborhood-level building } \\
\text { analyses provided evidence for } \\
\text { increased depressive symptom score } \\
\text { among adolescent males only residing } \\
\text { in neighborhoods with poorer building } \\
\text { conditions, in both unadjusted and } \\
\text { adjusted results. }\end{array}$ & $\begin{array}{l}\text { Uddin et al., } \\
2011\end{array}$ \\
\hline & $\begin{array}{l}\text { 5-HTTLPR }(\mathrm{L} / \mathrm{S}) \\
\text { monoamine } \\
\text { oxidase } \\
\text { A-upstream } \\
\text { variable number } \\
\text { tandem repeat } \\
\text { (MAOA-UVNTR) }\end{array}$ & $\begin{array}{l}\text { Depressive Symptoms: } \\
\text { Children's Depression } \\
\text { Inventory (CDI) }\end{array}$ & $\begin{array}{l}\text { Negative life events } \\
\text { (NLE) }\end{array}$ & $\begin{array}{l}129 \text { female, } \\
180 \text { male }\end{array}$ & $\begin{array}{l}89.3 \% \text { were White, } \\
1.7 \% \text { African } \\
\text { American, } 1.7 \% \\
\text { Hispanic, } 1.2 \% \\
\text { American } \\
\text { Indian/Alaskan, and } \\
6.15 \% \text { biracial or } \\
\text { multiracial. }\end{array}$ & Self-reported & $\begin{array}{l}\text { Longitudinal } \\
\text { Study }\end{array}$ & $\begin{array}{l}\text { 1. Girls were most likely to exhibit } \\
\text { elevated depressive symptoms when } \\
\text { experiencing NLE if they possessed } \\
\text { low-expression MAOA-uVNTR alleles } \\
\text { and short 5-HTTLPR alleles } \\
\text { 2. Low-expression MAOA-UVNTR alleles } \\
\text { but long 5-HTTLPR alleles were } \\
\text { implicated in boys at the age of } 13\end{array}$ & $\begin{array}{l}\text { Priess-Groben } \\
\text { and Hyde, } \\
2013\end{array}$ \\
\hline
\end{tabular}




\begin{tabular}{|c|c|c|c|c|c|c|c|c|c|}
\hline Age & Gene & $\begin{array}{l}\text { Measurement } \\
\text { instruments }\end{array}$ & Environmental factor & $\begin{array}{l}\text { Gender } \\
\text { composition }\end{array}$ & $\begin{array}{l}\text { Demographic } \\
\text { Characteristics }\end{array}$ & $\begin{array}{l}\text { Source of } \\
\text { information } \\
\text { (informant) }\end{array}$ & Study Design & Result & References \\
\hline & $\begin{array}{l}\text { Brain-derived } \\
\text { neurotrophic factor } \\
\text { (BDNF) val66met } \\
\text { and the serotonin } \\
\text { transporter region } \\
5-H T T L P R(L / S) \text {, }\end{array}$ & $\begin{array}{l}\text { depressive symptoms: } \\
\text { Beck Depression } \\
\text { Inventory-II (BDI-II) }\end{array}$ & $\begin{array}{l}\text { Family environment } \\
\text { quality }\end{array}$ & $\begin{array}{l}140 \text { males, } 223 \\
\text { females }\end{array}$ & $\begin{array}{l}92 \% \text { White, } 1.5 \% \\
\text { Asian, } 6 \% \text { biracial, } \\
\text { and } 0.5 \% \text { other } / \text { not } \\
\text { reported }\end{array}$ & $\begin{array}{l}\text { Interview and } \\
\text { self-report } \\
\text { t }\end{array}$ & $\begin{array}{l}\text { Longitudinal } \\
\text { Study }\end{array}$ & $\begin{array}{l}\text { After age } 15 \text {, the interaction of } \\
\text { cumulative plasticity genotype (defined } \\
\text { as presence of neither, either, or both } \\
5 \text {-HTTLPR S and val66met Met alleles) } \\
\text { and early family environment quality } \\
\text { was only predictive of depression } \\
\text { among females }\end{array}$ & $\begin{array}{l}\text { Dalton et al., } \\
2014\end{array}$ \\
\hline $\begin{array}{l}\text { The average } \\
\text { age } 15.5 \text { years }\end{array}$ & 5-HTTLPR (L/S) & $\begin{array}{l}\text { Depression symptoms: } \\
17 \text {-item version of the } \\
\text { Center for Epidemiologic } \\
\text { Studies Depression } \\
\text { Scale (CES-D; }\end{array}$ & Family support & $56 \%$ of boys & Caucasian & $\begin{array}{l}\text { Self-report } \\
\text { in-home } \\
\text { interview }\end{array}$ & $\begin{array}{l}\text { Cross-sectional } \\
\text { Study }\end{array}$ & $\begin{array}{l}\text { In the presence of poor family support, } \\
\text { boys with at least one short allele had } \\
\text { more symptoms of depression. in the } \\
\text { presence of high family support, boys } \\
\text { with the short allele had the fewest } \\
\text { depression symptoms }\end{array}$ & Li et al., 2013 \\
\hline $\begin{array}{l}\text { Mean age } \\
38.3 \pm 10.3 \\
\text { years }\end{array}$ & 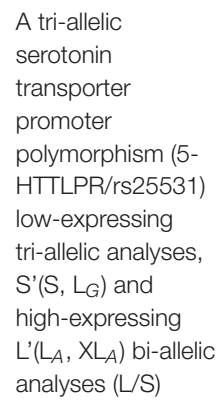 & $\begin{array}{l}\text { Beck Depression } \\
\text { Inventory (BDI) } \\
\text { Maudsley Personality } \\
\text { Inventory (MPI) }\end{array}$ & & $\begin{array}{l}550 \text { men, } 589 \\
\text { women }\end{array}$ & $\begin{array}{l}\text { Healthy Han } \\
\text { Chinese }\end{array}$ & Self-report & $\begin{array}{l}\text { Cross-sectional } \\
\text { Study }\end{array}$ & $\begin{array}{l}\text { 1. Tri-allelic genotype-by-gender } \\
\text { interaction: } S^{\prime} S^{\prime} \text { homozygotic were } \\
\text { associated with higher neuroticism and } \\
\text { BDI scores in men. } \\
\text { 2. Women showed a non-significant } \\
\text { pattern across both the 5-HTTLPR } \\
\text { classifications } \\
\text { 3. In the bi-allelic analyses, there was } \\
\text { only an association between SS } \\
\text { genotype and MPI-neuroticism in men }\end{array}$ & $\begin{array}{l}\text { Chang et al., } \\
2017\end{array}$ \\
\hline $\begin{array}{l}\text { Aged from } 14 \\
\text { to } 18\end{array}$ & 5-HTTLPR (L/S) & $\begin{array}{l}\text { Depressive symptoms: } \\
\text { Center for } \\
\text { Epidemiological Studies } \\
\text { Depression Scale } \\
\text { (CES-D) }\end{array}$ & Negative life events & $\begin{array}{l}131 \text { females } \\
\text { and } 121 \text { males }\end{array}$ & $\begin{array}{l}\text { Chinese healthy } \\
\text { Han population }\end{array}$ & $\begin{array}{l}\text { Self-report } \\
\text { interview }\end{array}$ & $\begin{array}{l}\text { Longitudinal } \\
\text { Study }\end{array}$ & $\begin{array}{l}\text { No main effect of } 5 \text {-HTTLPR } \\
\text { A significant } 5 \text {-HTLPR } \times \text { stress } \\
\text { interaction in females only. Females } \\
\text { with at least one } 5 \text {-HTTLPR } S \text { allele } \\
\text { exhibited more depressive symptoms } \\
\text { under stressful situations. No significant } \\
5 \text {-HTTLPR } \times \text { stress interaction was } \\
\text { found in males }\end{array}$ & $\begin{array}{l}\text { Ming et al., } \\
2013\end{array}$ \\
\hline
\end{tabular}




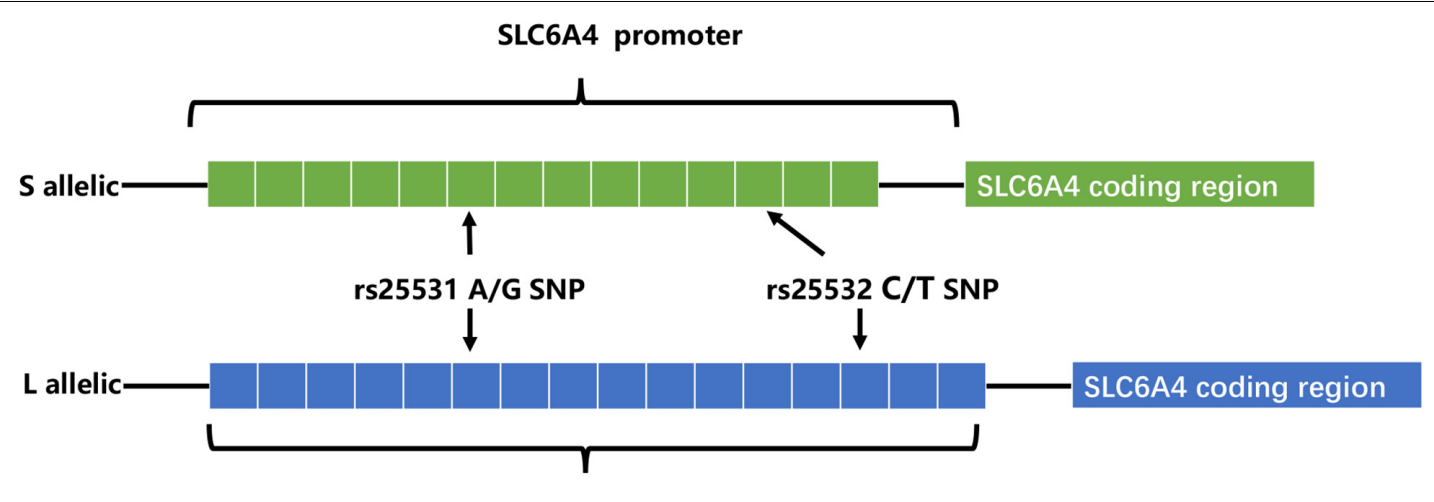

5-HTT gene-linked polymorphic region

FIGURE 1 | SLC6A4 $L$ and S allelic.

genetics attempts to locate the genes for gender differences in depression. At present, most candidate gene association studies have examined the relationship between serotonin system genes, dopamine system genes and depression (Table 2): loci implicated in the serotonin (5HT) system including serotonin (5$\mathrm{HT}$ ) transporter gene-linked promoter region (5-HTTLPR), 5HT receptor $2 \mathrm{~A}$ (5HT2A), 5HT receptor $2 \mathrm{C}$ (5HT2C), monoamine oxidase type A (MAOA), tryptophan hydroxylase (TPH1). loci implicated in the dopamine system including catechol-Omethyltransferase (COMT), dopamine receptor genes DRD1DRD5. Related candidate genes can regulate the level of neurotransmitters (serotonin or dopamine) in the synaptic space through degradation (e.g., MAOA, COMT) and transport (such as 5-HTTLPR), and can also change the number of receptors in the brain (5HT2A, DRD2 gene) to regulate signal transmission, which in turn affects the level of individual depression.

Recently, extensive works of literature have investigated the relationships between 5-HTTLPR and depression, the serotonin transporter gene-linked promoter region (5-HTTLPR) is a variable number tandem repeats (VNTR) located in the promoter region of SLC6A4 (the human 5-HTT-encoding gene) (Iurescia et al., 2016). In addition to most common alleles: the short (S, 14 repeats) and the long (L, 16 repeats), there are less common alleles: extra-long (XL, 17-24 repeats) and extra-short (XS, 1113 repeats). The $\mathrm{L}$ allele possesses higher transcriptional activity and serotonin uptake rate than $S$ allele positively affects serotonin reuptake rate. Also, two nearby single nucleotide polymorphisms (SNPs) rs25531 and 25532 (located in the 5-HTTLPR) contribute to the functional variations of SLC6A4 expression (Iurescia et al., 2016; Figure 1). The 5-HT transporter (5-HTT), an integral membrane protein, moves 5 -HT from synaptic space into presynaptic neurons (Damsbo et al., 2019; Möller et al., 2019). And then 5-HT was degraded by MAOA or recycled into synaptic vesicles. Duration and magnitude of 5-HT biological actions are closely related to 5HTT (Coleman et al., 2019). Also, effective drugs selective serotonin reuptake inhibitors (SSRIs), act on 5-HT transporter (Ananth et al., 2018; Kulikov et al., 2018). So, dysfunction in 5HTT leads to psychiatric disorders including depression.

\section{Genes Directly Affect Depression in a Gender-Specific Manner}

Different genes may directly affect depression in a genderspecific manner. 5HT2A, TPH may be a risk gene for depression in women, and COMT may have a greater impact on men. The relationship between 5-HTTLPR genotype and depression is highly controversial: although females carrying short alleles had a lower risk of depression than other genotypes (Table 2), these research results show inconsistent conclusions on specific genotypes (Eley et al., 2004; Aslund et al., 2009; Uddin et al., 2010). Animal studies have shown that individuals carrying short alleles, especially female animals, are more vulnerable to chronic stressors (Spinelli et al., 2012). But, Others showed no main effect of 5-HTTLPR on depression, which means 5-HTTLPR genotype cannot predict depression risk (Aslund et al., 2009; Risch et al., 2009; Ming et al., 2013). The study also indicated the main effects of 5HT2A, TPH on depression group exist in female subjects only (Eley et al., 2004). However, another study found direct effects of certain depression-related genes only exist in the male population. Individuals carrying the Met/Met of COMT genotype are less likely to suffer depression than those carrying the Val/Val genotype (Baekken et al., 2008).

In addition to candidate gene association studies, GWAS is another research strategy in the field of molecular genetics to find genes associated with individual psychological or behavioral phenotypes. Recent GWAS has identified 14 independent and replicated loci that were associated with MDD at the genomewide level (Maul et al., 2020). Only a few scientists have reported gene loci related to gender differences in depression: SNP rs6602398, presented in interleukin receptor 2A gene (IL2RA), was significantly associated with males MDD (Powers et al., 2016); 2 SNPs rs619002 and rs644926, presented in the EHdomain containing 3 (EHD3) gene, were associated with female MDD (Wang et al., 2014). However, some scientists showed no evidence for genetic heterogeneity between the gender using GWAS summary statistics (Trzaskowski et al., 2019).

Candidate gene association studies and Genome-wide association studies (GWAS) are research methods in 
developmental-behavioral genetic, aiming to find out whether genetics and environment affect human psychology and behavior development. Candidate gene association research is to directly select genes that may be related to individual psychological or behavioral phenotype variation based on existing genetic related information, biological related information, or empirical research results and then to determine whether a candidate gene is associated with this phenotype by case-control study or population-based association analysis. GWAS selects SNPs associated with individual psychological or behavioral phenotypes from sequence variations (single nucleotide polymorphism, SNP) throughout the human genome. The difference from candidate gene research strategies is that you do not need to know the function and characteristics of genes in advance. Also, there are no preset research assumptions. It offers opportunities for finding unknown susceptibility genes. Though more and more depression loci are identified, most GWAS has not yet made a replicable discovery of MDD (Hyde and Mezulis, 2020). Also, the GWAS study of depression has not achieved the same success as other mental illnesses; the complexity of the genetics and phenotype of depression may mean that a GWAS study will require a sample of thousands of participants (Howard et al., 2019). Compared with the huge cost of GWAS, candidate gene association studies are more economica and faster.

\section{Gene-Environment Interaction Contribute to the Risk of Depression}

Many studies suggest 5HTTLPR-negative environment interaction contributes to the risk of depression in the child, adolescent, and adult populations in a gender-specific manner (Table 2). Also, sex modulates 5-HTTLPR genotype-childhood adversity interaction on hippocampal volume [reducing hippocampal volume in depressed patients (Maller et al., 2018)] (Everaerd et al., 2012). But, results remain inconclusive. Some studies have shown females rather than males carrying the SS genotype of 5-HTTLPR tended to develop depressive symptoms under negative environment (Eley et al., 2004; Aslund et al., 2009; Hammen et al., 2010; Ming et al., 2013) or females carrying $\mathrm{S}$ allele are easier to develop depressive symptoms under negative environment (Sjöberg et al., 2006; Brummett et al., 2008; Hammen et al., 2010; Ming et al., 2013). However, many contradictions about 5HTTLPR-negative environment exist in males: the 1 allele-stressor interaction contributes to higher depression scores as compared to those control group and s allele (Brummett et al., 2008); Uddin et al. (2010) showed an interaction between SL genotype and deprived counties predicted lowered risk of depressive symptoms in males; Li et al. (2013) showed the interaction between poor family support and SL genotype predicted more symptoms of depression in males; Other studies showed SS genotype-negative environment interaction predicted higher risks of depression, a statistically significant only in males (Li et al., 2013; Haberstick et al., 2016; Chang et al., 2017). Basically consistent conclusion exist in the females but not males. Under negative environment, females carrying $\mathrm{S}$ alleles have higher depression levels. But, A MetaAnalysis of Interaction between 5-HTTLPR, stressful life events, and risk of depression, published in 2009, neither 5-HTTLPR genotypes alone or interaction with stressful life events predicted an increased risk of depression in females alone, males alone, or in both genders combined. The Meta-Analysis across 14 studies, subjects of most studies are adults (Risch et al., 2009).

Several reasons can explain the divergence of the above conclusions. First, Different countries and races have different distributions of alleles and genotypes of the 5-HTTLPR: e.g., different frequency of $\mathrm{S} / \mathrm{S}$ and $\mathrm{L} / \mathrm{L}$ genotype between older Taiwanese adults and western groups (Goldman et al., 2010); the higher frequency of $S$ alleles in Asians than in Caucasians (Iurescia et al., 2016). Second, the dichotomous classification (S/L) of 5-HTTLPR genotypes may lead to influenced research results. Increased length of the 5HTTLPR may be associated with increased gene expression ( $\mathrm{S}<\mathrm{L}<\mathrm{XL}$ ) (Vijayendran et al., 2012). But, dichotomous classification of 5-HTTLPR genotypes exists in most studies (Table 2). Third, neglecting the two nearby SNPs rs25531 and 25532 may lead to a contradictory conclusion. SNP rs25531 contributes to different allelic subtypes $\mathrm{S}_{\mathrm{A}}, \mathrm{S}_{G}, \mathrm{~L}_{\mathrm{A}}$, and $\mathrm{L}_{G}$. The different expression abilities exist in $\mathrm{L}_{\mathrm{A}} / \mathrm{L}_{\mathrm{A}}$ genotype AND $\mathrm{S} / \mathrm{S}, \mathrm{S} / \mathrm{L}_{G}, \mathrm{~L}_{G} / \mathrm{L}_{G}, \mathrm{~L}_{\mathrm{A}} / \mathrm{L}_{G}$. Fourth, geneenvironment interaction may be more successful for studies that study a single gene with big environmental impact. For example, uninfected control group subjects, carrying 32 mutation in the $\triangle$ CCR5 chemokine receptor, were less infected with human immunodeficiency virus when they were highly exposed to the virus (Risch et al., 2009). However, The inheritance of depression does not follow a single-gene inheritance pattern like Huntington's disease but has a non-Mendelian, polygenic underpinning. As a complex psychological problem, depression is most likely the result of the synergistic effects of multiple genetic and environmental factors (Cao et al., 2018). In recent years, the studies of polygenic risk scores and gene-gene interaction studies have proved additive and interactive genetic effects of depression. Also, multi-genes affect the development of depression through interaction with environmental factors and gender differences exist in this complex interaction (Cao et al., 2016). e.g., Girls rather than boys possessed low-expression MAOA-uVNTR alleles and S 5-HTTLPR alleles, more likely to show increased depressive symptoms under stressful life events (Priess-Groben and Hyde, 2013). The interaction of both plasticity genotype (5-HTTLPR S and val66met Met allele)- early family environment quality predicted more depressive symptoms than either or neither plasticity genotype only in females (Dalton et al., 2014). Fifth, different study design, longitudinal study, and cross-sectional study have their advantages and disadvantages (Table 3). The cross-sectional study is a comparative study of people of different age groups at the same time (intergroup comparison), and the longitudinal study is a continuous study of the same population in various years (self-comparison). Sixth, different gene-environment results between objective measures (i.e., independent of the participants' report) and subjective measures (i.e., self-report) (Uddin et al., 2011), results of self-reported are more subjective (Sjöberg et al., 2006). Moreover, gene-environment interaction has a dynamic effect on depression. In a study of the influence of BDNF Val66met and 5-HTTLPR on depressive symptoms, Scientists report 
TABLE 3 | Comparison of advantages and disadvantages between longitudinal research and cross-sectional research.

\begin{tabular}{|c|c|c|}
\hline & Longitudinal Study & Cross-sectional Study \\
\hline Advantages & $\begin{array}{l}\text { 1. No intergenerational effect } \\
\text { 2. Systematically evaluate the } \\
\text { behavioral changes of the } \\
\text { subjects }\end{array}$ & $\begin{array}{l}\text { 1. Higher efficiency of data } \\
\text { collection } \\
\text { 2. Lower Research and } \\
\text { control cost } \\
\text { 3. Less affected by the loss } \\
\text { of subjects }\end{array}$ \\
\hline Disadvantages & $\begin{array}{l}\text { 1. Time-consuming } \\
\text { 2. Higher Research and control } \\
\text { cost } \\
\text { 3. Loss of subjects brings } \\
\text { confounding variables } \\
\text { 4. Only observing the changes of } \\
\text { one group, whether it has } \\
\text { universal significance is still in } \\
\text { doubt }\end{array}$ & $\begin{array}{l}\text { 1. More confusion variables } \\
\text { 2. Can't systematically } \\
\text { evaluate the behavioral } \\
\text { changes of the subjects }\end{array}$ \\
\hline
\end{tabular}

that the gene-environment interaction conforms to differential susceptibility model when women are 15 years and that geneenvironment interaction conforms to the diathesis-stress model after 15 years (Figure 2). Finally, measurement instruments, environmental factors, and source of information (informant) highly divergent across studies, so limiting the comparability and replication of the studies.

Besides, a SNP of the HTR2C gene, rs6318 (Ser23Cys), is Related to women's depressive symptoms with high stress levels and different cortisol release (Brummett et al., 2014). related genes of dopamine system (DRD2, COMT) (Vaske et al., 2009; Nyman et al., 2011), HPA axis system (CRHR1) (Roy et al., 2018), and immune system (IL-1 $\beta$ SNP) (McQuaid et al., 2019), can also interact with the environment to affect the occurrence of depression in a gender-specific manner (Table 4).
Chinese scientists longitudinally studied the relationship of BDNF Val66Met (Fan et al., 2017), Preproghrelin Leu72Met (Su et al., 2017), oestrogen receptor alpha gene (ESR1) rs9340799 (Feng et al., 2017), adiponectin rs1501299 (Wang et al., 2015), tumor necrosis factor receptor-II (TNF-RII) rs1061622 (Memon et al., 2018) and insertion/deletion polymorphism at angiotensinconverting enzyme gene (ACE I/D) (Fan et al., 2018)with depression in adolescents after the 2008 Wenchuan earthquake. Results showed gene-environment interaction contributes to the risk of depression after the earthquake in a gender- and timedependent manner. Dynamic genetic effects on depression across development were proved once again. However, the scientists also explained that their research is either different from previous research results or rarely reported. Therefore, we cannot yet draw a definitive conclusion on gender differences.

\section{FUTURE DIRECTIONS}

To date, few pieces of research have investigated gender differences in the polygenetic mechanisms of depression, and ignoring gender specificity may lead to inconsistent results. As a complex psychological problem, depression is most likely the result of the synergistic effects of multiple genetic and environmental factors (Cao et al., 2018). Therefore, future studies should further investigate the role of gender in the regulation of polygene genetic mechanisms (Cao et al., 2016). Second, gender differences in the genetic basis of depression may be caused by differences in the sensitivity of individuals to different types of environments (Cao et al., 2013). Future studies should examine the interaction between different types of the environment and genetic genes that affect gender differences in depression. The theoretical basis of the existing molecular genetics research on depression is mostly the "diathesis-stress

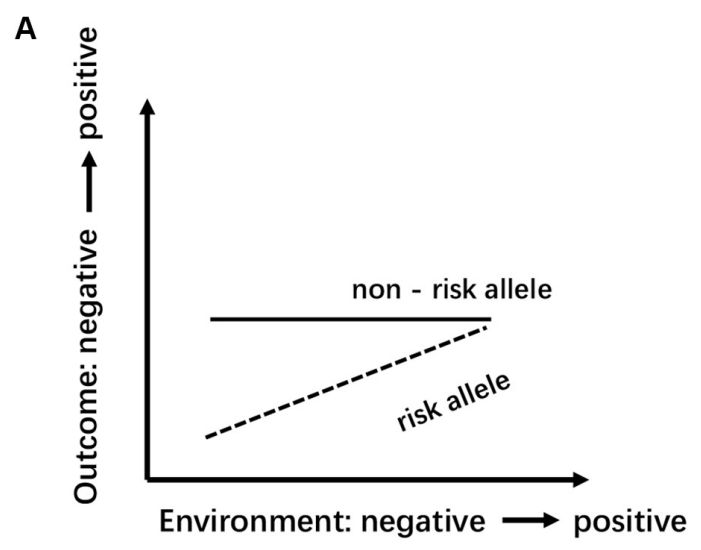

diathesis-stress model

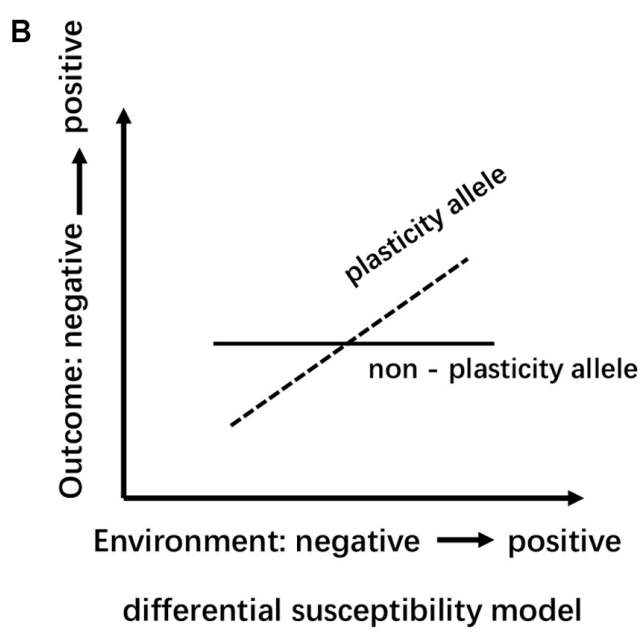

differential susceptibility model

FIGURE 2 | Schematic diagram of the model of differential susceptibility and diathesis-stress: the abscissa represents the transition of environment factors from negative to positive; the ordinate indicates that the outcome variable range from negative to positive. (A) Diathesis-stress model points out that individuals with "risk" allele are only more likely to be negatively affected and to develop poorly than those with the "non-risk" allele. (B) Differential susceptibility model view, compared with the "non-plastic" allele carriers, "plastic" alleles individual has better sensitivity, more sensitive to both positive and negative environment accordingly develop better or worse. 
TABLE 4 | Gene-environment interaction contribute to the risk of depression.

\begin{tabular}{|c|c|c|c|c|c|c|c|c|c|}
\hline Age & Gene & $\begin{array}{l}\text { Measurement } \\
\text { instruments }\end{array}$ & $\begin{array}{l}\text { Environmenta } \\
\text { stress factor }\end{array}$ & $\begin{array}{l}\text { aGender } \\
\text { composition }\end{array}$ & $\begin{array}{l}\text { Demographic } \\
\text { Characteristics }\end{array}$ & $\begin{array}{l}\text { Source of } \\
\text { information } \\
\text { (informant) }\end{array}$ & Methodology & Result & References \\
\hline \multirow[t]{3}{*}{$\begin{array}{l}\text { Waves II and III } \\
\text { (18-27) of the } \\
\text { National } \\
\text { Longitudinal Study } \\
\text { of Adolescent } \\
\text { Health (Add Health) }\end{array}$} & DRD2 & $\begin{array}{l}\text { Depressive symptoms: } \\
\text { Center for } \\
\text { Epidemiologic } \\
\text { Studies-Depression } \\
\text { Scale }\end{array}$ & $\begin{array}{l}\text { : Violent } \\
\text { Victimization }\end{array}$ & & $\begin{array}{l}\text { African American, } \\
\text { Caucasian }\end{array}$ & $\begin{array}{l}\text { self-reported in-home } \\
\text { interviews }\end{array}$ & $\begin{array}{l}\text { Cross-sectional } 1 \\
\text { Study }\end{array}$ & $\begin{array}{l}\text { 1. Violent victimization has a strong } \\
\text { independent effect on depressive } \\
\text { symptoms for Caucasian females. } \\
\text { violent victimization is associated with } \\
\text { higher levels of depressive symptoms } \\
\text { among African American females when } \\
\text { they carry at least one A1 allele of } \\
\text { DRD2. } \\
\text { 2. DRD2 has a significant independent } \\
\text { effect on depressive symptoms for } \\
\text { males and African American females }\end{array}$ & $\begin{array}{l}\text { Vaske et al., } \\
2009\end{array}$ \\
\hline & $\begin{array}{l}\text { Corticotrophin- } \\
\text { releasing hormone } \\
\text { receptor-1 gene } \\
\text { (CRHR1) variant } \\
\text { (rs17689918) }\end{array}$ & $\begin{array}{l}\text { Depressive symptoms: } \\
\text { Montgomery-Åsberg } \\
\text { Depression Rating } \\
\text { Scale; mood disorders: } \\
\text { Mini-International } \\
\text { Neuropsychiatric } \\
\text { Interview }\end{array}$ & $\begin{array}{l}\text { Stressful life } \\
\text { events (SLE) }\end{array}$ & $52.5 \%$ females & European origin & $\begin{array}{l}\text { Self- and } \\
\text { parent-reports }\end{array}$ & $\begin{array}{l}\text { Longitudinal } \\
\text { Study }\end{array}$ & $\begin{array}{l}\text { 1. A-allele males and GG females with } \\
\text { higher SLEs reported greater } \\
\text { depressiveness at age } 18 \\
\text { 2. Low SLE was associated with a lower } \\
\text { risk for depression in males with the GG } \\
\text { genotype at age } 15\end{array}$ & $\begin{array}{l}\text { Roy et al., } 2018 \\
\text { G } \\
\text { G }\end{array}$ \\
\hline & $\begin{array}{l}\text { SLC6A4, TPH2, } \\
\text { COMT, MAOA, and } \\
\text { the dopamine } \\
\text { receptor genes } \\
\text { DRD1-DRD5. }\end{array}$ & $\begin{array}{l}\text { depressive symptoms: } \\
\text { HSCL questionnaire }\end{array}$ & $\begin{array}{l}\text { 1. Early } \\
\text { developmental } \\
\text { risk } \\
\text { 2. Social } \\
\text { environment } \\
\text { risk }\end{array}$ & 2509 males, 2716 & $\begin{array}{l}\text { genetically isolated } \\
\text { population-based } \\
\text { Northern Finland Birth } \\
\text { Cohort }\end{array}$ & Self-report & $\begin{array}{l}\text { Longitudinal } \\
\text { Study } \\
\end{array}$ & $\begin{array}{l}\text { 1. No major genetic effects of the } \\
\text { analyzed variants on depressiveness. } \\
\text { Rs } 4274224 \text { from DRD2 shows a } \\
\text { significant association with } \\
\text { depressiveness in males } \\
\text { 2. Allelic variants of COMT interacted } \\
\text { with high early developmental risk } \\
\text { associated with depression in males }\end{array}$ & $\begin{array}{l}\text { Nyman et al., } \\
2011\end{array}$ \\
\hline \multirow[t]{2}{*}{$\begin{array}{l}\text { Carleton University } \\
\text { first-year students }\end{array}$} & $\begin{array}{l}\text { y IL-1 } \beta \text { rs16944, IL-6 } \\
\text { rs1800795 SNP, } \\
\text { TNF- } \alpha \text { rs1800629 }\end{array}$ & $\begin{array}{l}\text { Depressive Symptoms: } \\
21 \text {-item Beck } \\
\text { Depression Inventory } \\
\text { (BDI) }\end{array}$ & $\begin{array}{l}\text { s:Childhood } \\
\text { Maltreatment }\end{array}$ & $\begin{array}{l}343 \text { females and } \\
132 \text { males }\end{array}$ & $\begin{array}{l}\text { various ethnic } \\
\text { backgrounds }\end{array}$ & Self-report & $\begin{array}{l}\text { Cross-sectional } \\
\text { Study }\end{array}$ & $\begin{array}{l}\text { Among females, higher childhood } \\
\text { maltreatment was accompanied by } \\
\text { elevated depressive symptoms } \\
\text { irrespective of the IL-1 } 1 \beta \text { SNP, but } \\
\text { among males, this relationship was } \\
\text { particularly pronounced for those } \\
\text { carrying the GG genotype of the IL-1 } 1 \beta \\
\text { SNP. }\end{array}$ & $\begin{array}{l}\text { McQuaid et al., } \\
2019\end{array}$ \\
\hline & $\begin{array}{l}\text { HTR2C gene, rs6318 } \\
\text { (Ser23Cys) }\end{array}$ & $\begin{array}{l}\text { 8Depressive symptoms: } \\
\text { brief CES-D }\end{array}$ & $\begin{array}{l}\text { : Stressful life } \\
\text { events }\end{array}$ & $\begin{array}{l}\text { Men 2,366, Womert } \\
2,712\end{array}$ & rWhite & Self-report & Cross-sectional & $\begin{array}{l}\text { Homozygous Ser2 } 23 \mathrm{C} \text { women who } \\
\text { reported high levels of life stress had } \\
\text { depressive symptom scores that were } \\
\text { about } 0.3 \text { standard deviations higher } \\
\text { than female Cys } 23 \mathrm{G} \text { carriers with } \\
\text { similarly high stress levels. }\end{array}$ & $\begin{array}{l}\text { Brummett } \\
\text { et al., } 2014\end{array}$ \\
\hline
\end{tabular}

- depressive symptoms: 1. Early 2509 males, 2716 genetically isolated Selfort COMT MAOA, and HSCL questionnaire developmental females population-based

receptor genes

risk 
TABLE 4 | Continued

\begin{tabular}{|c|c|c|c|c|c|c|c|c|c|}
\hline Age & Gene & $\begin{array}{l}\text { Measurement } \\
\text { instruments }\end{array}$ & $\begin{array}{l}\text { Environmental } \\
\text { stress factor }\end{array}$ & $\begin{array}{l}\text { Gender } \\
\text { composition }\end{array}$ & $\begin{array}{l}\text { Demographic } \\
\text { Characteristics }\end{array}$ & $\begin{array}{l}\text { Source of } \\
\text { information } \\
\text { (informant) }\end{array}$ & Methodology & Result & References \\
\hline $\begin{array}{l}\text { High school } \\
\text { (grades 11-12) }\end{array}$ & BDNF Val66Met & $\begin{array}{l}\text { Depression } \\
\text { severity: Beck } \\
\text { Depression } \\
\text { Inventory (BDI) }\end{array}$ & $\begin{array}{l}\text { Wenchuan } \\
\text { Earthquake }\end{array}$ & $\begin{array}{l}\text { Males 306, } \\
\text { Females } 399\end{array}$ & Chinese Han & Self-report & $\begin{array}{l}\text { Longitudinal } \\
\text { Study }\end{array}$ & $\begin{array}{l}\text { 1. Females constantly had higher } \\
\text { depression prevalence than the males } \\
\text { during the follow-up in the Met allele } \\
\text { carriers } \\
\text { 2. Compared to that at } 6 \text { months, the } \\
\text { prevalence was lowered at } 12 \text { months } \\
\text { in the male Met allele carriers, and at } \\
18 \text { months in all the females and the } \\
\text { male Met allele carriers. }\end{array}$ & Fan et al., 2017 \\
\hline $\begin{array}{l}\text { High school } \\
\text { (grades 11-12) }\end{array}$ & $\begin{array}{l}\text { Preproghrelin } \\
\text { Leu72Met }\end{array}$ & $\begin{array}{l}\text { Beck Depression } \\
\text { Inventory (BDI) }\end{array}$ & $\begin{array}{l}\text { Wenchuan } \\
\text { Earthquake }\end{array}$ & & Chinese Han & Self-report & $\begin{array}{l}\text { Longitudinal } \\
\text { Study }\end{array}$ & $\begin{array}{l}\text { 1. Females had a higher prevalence of } \\
\text { depression than males at } 6 \text { months } \\
\text { after the earthquake in } 72 \text { Leu/Leu } \\
\text { homozygotes } \\
\text { 2. The prevalence was consecutively } \\
\text { decreased in male } 72 \mathrm{Met} \text { allele carriers, } \\
\text { but not in male } 72 \text { Leu/Leu } \\
\text { homozygotes, female } 72 \mathrm{Met} \text { allele } \\
\text { carriers, or female } 72 \text { Leu/Leu } \\
\text { homozygotes during follow-up }\end{array}$ & Su et al., 2017 \\
\hline $\begin{array}{l}439 \text { Chinese Han } \\
\text { adolescents }\end{array}$ & $\begin{array}{l}\text { Oestrogen receptor } \\
\text { alpha gene (ESR1) } \\
\text { rs9340799 }\end{array}$ & $\begin{array}{l}\text { Beck Depression } \\
\text { Inventory (BDI) }\end{array}$ & $\begin{array}{l}\text { Wenchuan } \\
\text { Earthquake }\end{array}$ & $\begin{array}{l}\text { Males 197, } \\
\text { Females } 242\end{array}$ & Chinese Han & Self-report & $\begin{array}{l}\text { Longitudinal } \\
\text { Study }\end{array}$ & $\begin{array}{l}\text { ESR1 rs9340799 maybe not } \\
\text { associated with neither the prevalence } \\
\text { nor the severity of depression in male } \\
\text { individuals, but in female }\end{array}$ & $\begin{array}{l}\text { Feng et al., } \\
2017\end{array}$ \\
\hline Grade 11-12 & $\begin{array}{l}\text { Adiponectin } \\
\text { rs1501299 }\end{array}$ & $\begin{array}{l}\text { Beck Depression } \\
\text { Inventory (BDI) }\end{array}$ & $\begin{array}{l}\text { Wenchuan } \\
\text { earthquake. }\end{array}$ & $\begin{array}{l}\text { Males 233, } \\
\text { Females } 304\end{array}$ & Chinese Han & Self-report & $\begin{array}{l}\text { Longitudinal } \\
\text { Study }\end{array}$ & $\begin{array}{l}\text { 1. The decreases of the scores were } \\
\text { found in the male subjects regardless of } \\
\text { the genotypes in the time course of } 6 \text {, } \\
\text { 12, and } 18 \text { months after the } \\
\text { earthquake. } \\
\text { 2. The scores were decreased in the } \\
\text { female T carriers, but not in the female } \\
\text { GG homozygotes at } 18 \text { months when } \\
\text { compared with those at } 12 \text { months } \\
\text { after the earthquake. }\end{array}$ & $\begin{array}{l}\text { Wang et al., } \\
\text { f } 2015\end{array}$ \\
\hline $\begin{array}{l}\text { High school } \\
\text { students }\end{array}$ & $\begin{array}{l}\text { Tumor necrosis factor } \\
\text { receptor-II (TNF-RII) } \\
\text { rs1061622 }\end{array}$ & $\begin{array}{l}\text { Beck Depression } \\
\text { Inventory (BDI) }\end{array}$ & $\begin{array}{l}\text { Wenchuan } \\
\text { earthquake }\end{array}$ & $\begin{array}{l}\text { Males 197, } \\
\text { Females } 242\end{array}$ & Chinese Han & Self-report & $\begin{array}{l}\text { Longitudinal } \\
\text { Study }\end{array}$ & $\begin{array}{l}\text { 1. Female } \Pi \text { homozygotes had a higher } \\
\text { depression prevalence than the male } T \\
\text { homozygotes at } 6,12 \text {, and } 18 \text { months. } \\
\text { 2. The female } G \text { allele carriers had a } \\
\text { higher depression prevalence than the } \\
\text { male } G \text { allele carriers only at } 6 \text { and } \\
12 \text { months after the earthquake3. BDI } \\
\text { scores declined in the male subjects } \\
\text { with both genotypes and only in the } \\
\text { female } G \text { allele carriers at } 12 \text { months } \\
\text { when compared with those at } 6 \text { months }\end{array}$ & $\begin{array}{l}\text { Memon et al., } \\
2018\end{array}$ \\
\hline
\end{tabular}




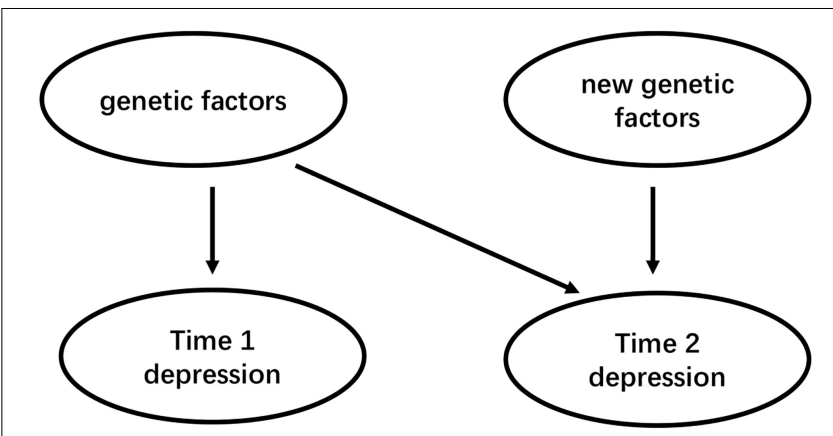

FIGURE 3 | The continuity and variability of genetic factors for depression.

model" because the many scientists believe that when individuals are under stress or high pressure, psychological and behavioral problems are prone to occur in individuals with a certain type of poor genetic quality, so studies based on this model mostly use the negative environment such as stressful life events as indicators to investigate the $\mathrm{G} \times \mathrm{E}$ effect of depression. However, the newly emerging theoretical model, the "differential susceptibility model," clearly puts forward and proves that individuals of certain genotypes are also more susceptible to the effects of positive growth environments and perform well or the opposite (Figure 2). Also, the existing research based on the "diathesis-stress model" fails to reveal multiple possible ways of $\mathrm{G} \times \mathrm{E}$ interaction. Whether there is a gender difference in the sensitivity of individuals with different genotypes to the positive environment is also needed for future research. Third, developmental behavioral genetics can investigate in depth whether genetics and the environment have an impact on human psychological and behavioral development and whether the effects were moderated by age. Compared to younger aged youth, older aged adolescents carrying SS/SL genotype has a higher risk of depressive episodes with greater chronic peer stress over the 3 years (Hankin et al., 2015). Besides, Depression is developmentally dynamic and may be affected by some new genetic factors across development (Figure 3). some new genetic factors emerge in depressive symptoms (Lau and Eley, 2006) or symptoms of anxiety and depression (Nivard et al., 2015) in adolescence. Compared with the 5-month-old baby, the negative emotionality of an 18-month-old baby was affected by persistent and new genetic factors (Schumann et al., 2017). So, it is necessary to use a longitudinal cohort design to investigate the gender differences in the genetic basis of depression at different ages and their developmental changes. Forth, Subjects suffering from mental disorders or various physical diseases may rate disease inaccurately (Chang et al., 2017). So, Selecting physically and mentally healthy, drug-free subjects to minimize these confounding factors and reveal the effect of the gene on depression more accurately. Finally, It is worth mentioning that to reduce the interference of confounding factors (e.g., ethnicity, gender, age, socioeconomic status), researchers should add the covariate $x$ environment and covariate $x$ gene interaction terms to the same model that tests the $\mathrm{G} \times \mathrm{E}$ interaction (Keller, 2014). 


\section{CONCLUSION}

There is not enough evidence for genetic heterogeneity in men and women with major depression (Piccinelli and Wilkinson, 2000; Maciej et al., 2019). Genetic markers of major depression have not been successfully identified. Similarly, specific susceptibility genes on the X chromosome have not been successfully identified (Hyde and Mezulis, 2020). As a heterogeneous and multifactorial disease, the gender gap in depression may be caused by many biological, psychological, micro and macro environmental factors with varying interactions (Piccinelli and Wilkinson, 2000; Kuehner, 2017). Heredity may play a role in explaining gender differences. But, no sufficient evidence can explain the gender difference in depression from genetic underpinnings. In future research, scientists should pay attention to the influence of confounding factors on the results. such as different types of environments (positive or negative), demographic characteristics, measurement instruments, study design and so on.

\section{REFERENCES}

Ananth, M. R., DeLorenzo, C., Yang, J., Mann, J. J., and Parsey, R. V. (2018). Decreased pretreatment amygdalae serotonin transporter binding in unipolar depression remitters: a prospective PET study. J. Nucl. Med. 59, 665-670. doi: 10.2967/jnumed.117.189654

Angold, A., and Worthman, C. W. (1993). Puberty onset of gender differences in rates of depression: a developmental, epidemiologic and neuroendocrine perspective. J. Affect. Disord. 29, 145-158. doi: 10.1016/0165-0327(93)90029-j

Aslund, C., Leppert, J., Comasco, E., Nordquist, N., Oreland, L., and Nilsson, K. W. (2009). Impact of the interaction between the 5HTTLPR polymorphism and maltreatment on adolescent depression. a population-based study. Behav. Genet. 39, 524-531. doi: 10.1007/s10519-009-9285-9

Baekken, P. M., Skorpen, F., Stordal, E., Zwart, J.-A., and Hagen, K. (2008). Depression and anxiety in relation to catechol-O-methyltransferase val158met genotype in the general population: the Nord-Trøndelag Health Study (HUNT). BMC Psychiatry 8:48. doi: 10.1186/1471-244X-8-48

Brummett, B. H., Babyak, M. A., Williams, R. B., Harris, K. M., Jiang, R., Kraus, W. E., et al. (2014). A putatively functional polymorphism in the HTR2C gene is associated with depressive symptoms in white females reporting significant life stress. PLoS One 9:e114451. doi: 10.1371/journal.pone.0114451

Brummett, B. H., Boyle, S. H., Siegler, I. C., Kuhn, C. M., Ashley-Koch, A., Jonassaint, C. R., et al. (2008). Effects of environmental stress and gender on associations among symptoms of depression and the serotonin transporter gene linked polymorphic region (5-HTTLPR). Behav. Genet. 38, 34-43. doi: 10.1007/s10519-007-9172-1

Cao, Y., Lin, X., Chen, L., Ji, L., and Zhang, W. (2018). The catechol-Omethyltransferase and dopamine transporter genes moderated the impact of peer relationships on adolescent depressive symptoms: a gene-geneenvironment study. J. Youth Adolesc. 47, 2468-2480. doi: 10.1007/s10964-0180925-3

Cao, Y. M., Wang, M. P., Cao, C., Chen, G. H., and zhang, W. X. (2013). Gender differences in the genetic underpinning of depression. Adv. Psychol. Sci. 21, 1605-1616. doi: 10.3724/sp.j.1042.2013.01605

Cao, Y. M., Wang, M. P., Cao, C., and zhang, W. X. (2016). The polygenic underpinnings of depression. Adv. Psychol. Sci. 24, 525-535. doi: 10.3724/sp. j.1042.2016.00525

Chang, C.-C., Chang, H.-A., Fang, W.-H., Chang, T.-C., and Huang, S.-Y. (2017). Gender-specific association between serotonin transporter polymorphisms (5HTTLPR and rs25531) and neuroticism, anxiety and depression in well-defined healthy Han Chinese. J. Affect. Disord. 207, 422-428. doi: 10.1016/j.jad.2016. 08.055

\section{AUTHOR CONTRIBUTIONS}

LZ wrote the first draft and participated in the discussion of the manuscript. LZ, GH, YZ, YJ, TG, WY, RC, SX, and BL made major revisions to the logic of this manuscript and provided the critical revisions. All authors approved the final version of the manuscript for submission.

\section{FUNDING}

This work was supported by grants from the National Natural Science Foundation of China (NSFC) (81871070 and 81971276), the National Key R\&D Program of China (Grant No. 2018YFC1311600), the Jilin Province Medical and Health Talents (2017F012, 2019SCZT007, and 2019SCZT013), the Jilin Science and Technology Agency (20170204049SF, 20190701078GH, 20200201465JC, and 20200301005RQ), and Scientific Research Foundation of the Education Department of Jilin Province (Grant No. JJKH20201107KJ).

Coleman, J. A., Yang, D., Zhao, Z., Wen, P. C., Yoshioka, C., Tajkhorshid, E., et al. (2019). Serotonin transporter-ibogaine complexes illuminate mechanisms of inhibition and transport. Nature 569, 141-145. doi: 10.1038/s41586-0191135-1

Dalton, E. D., Hammen, C. L., Najman, J. M., and Brennan, P. A. (2014). Genetic susceptibility to family environment: BDNF val66met and 5-HTTLPR influence depressive symptoms. J. Fam. Psychol. 28, 947-956. doi: 10.1037/fam0000032

Damsbo, A. G., Kraglund, K. L., Buttenschøn, H. N., Johnsen, S. P., Andersen, G., and Mortensen, J. K. (2019). Serotonergic regulation and cognition after stroke: the role of antidepressant treatment and genetic variation. Cerebrovasc. Dis. 47, 72-79. doi: 10.1159/000498911

Duman, R. S., Aghajanian, G. K., Sanacora, G., and Krystal, J. H. (2016). Synaptic plasticity and depression: new insights from stress and rapid-acting antidepressants. Nat. Med. 22, 238-249. doi: 10.1038/nm.4050

Eley, T. C., Sugden, K., Corsico, A., Gregory, A. M., Sham, P., McGuffin, P., et al. (2004). Gene-environment interaction analysis of serotonin system markers with adolescent depression. Mol. Psychiatry 9, 908-915. doi: 10.1038/sj.mp. 4001546

Everaerd, D., Gerritsen, L., Rijpkema, M., Frodl, T., van Oostrom, I., Franke, B., et al. (2012). Sex modulates the interactive effect of the serotonin transporter gene polymorphism and childhood adversity on hippocampal volume. Neuropsychopharmacology 37, 1848-1855. doi: 10.1038/npp.2012.32

Fan, M., Cao, T., Feng, Y., Su, M., Lin, J., Ran, M. S., et al. (2018). D allele of insertion/deletion polymorphism at angiotensin-converting enzyme gene is associated with reduced prevalence and severity of depression among Chinese adolescents at early stage after Wenchuan earthquake. Int. J. Psychiatry Clin. Pract. 22, 136-142. doi: 10.1080/13651501.2017.1383440

Fan, M., Li, R. H., Hu, M. S., Xiao, L. Y., Zhou, X. D., Ran, M. S., et al. (2017). Association of val66met polymorphism at brain derived neurotrophic factor gene with depression among Chinese adolescents after Wenchuan earthquake: an 18months longitudinal study. Physiol. Behav. 179, 16-22. doi: 10.1016/j. physbeh.2017.05.018

Feng, Y., Lin, J., Guo, Q., Su, M., Cao, T., Fan, M., et al. (2017). Longitudinal interactions of estrogen receptor alpha gene rs9340799 with social-environmental factors on depression in adolescents after Wenchuan earthquake. J. Clin. Neurosci. 45, 305-310. doi: 10.1016/j.jocn.2017.08.054

Ge, T., Fan, J., Yang, W., Cui, R., and Li, B. (2018). Leptin in depression: a potential therapeutic target. Cell Death Dis. 9:1096. doi: 10.1038/s41419-0181129-1

Goldman, N., Glei, D. A., Lin, Y.-H., and Weinstein, M. (2010). The serotonin transporter polymorphism (5-HTTLPR): allelic variation and links with depressive symptoms. Depress. Anxiety 27, 260-269. doi: 10.1002/da.20660 
Haberstick, B. C., Boardman, J. D., Wagner, B., Smolen, A., Hewitt, J. K., KilleyaJones, L. A., et al. (2016). Depression, stressful life events, and the impact of variation in the serotonin transporter: findings from the National Longitudinal Study of Adolescent to Adult Health (Add Health). PLoS One 11:e0148373. doi: 10.1371/journal.pone. 0148373

Hall, L. S., Adams, M. J., Arnau-Soler, A., Clarke, T.-K., Howard, D. M., Zeng, Y., et al. (2018). Genome-wide meta-analyses of stratified depression in Generation Scotland and UK Biobank. Transl. Psychiatry 8:9. doi: 10.1038/s41398-0170034-1

Hammen, C., Brennan, P. A., Keenan-Miller, D., Hazel, N. A., and Najman, J. M. (2010). Chronic and acute stress, gender, and serotonin transporter gene-environment interactions predicting depression symptoms in youth. J. Child Psychol. Psychiatry 51, 180-187. doi: 10.1111/j.1469-7610.2009. 02177.x

Hankin, B. L., Young, J. F., Abela, J. R. Z., Smolen, A., Jenness, J. L., Gulley, L. D., et al. (2015). Depression from childhood into late adolescence: influence of gender, development, genetic susceptibility, and peer stress. J. Abnorm. Psychol. 124, 803-816. doi: 10.1037/abn0000089

Harkness, K. L., Alavi, N., Monroe, S. M., Slavich, G. M., Gotlib, I. H., and Bagby, R. M. (2010). Gender differences in life events prior to onset of major depressive disorder: the moderating effect of age. J. Abnorm. Psychol. 119, 791-803. doi: $10.1037 / \mathrm{a} 0020629$

Hou, J. Q., Chen, Y., Li, Y., Yang, D., and Zhang, X. (2012). A behavioral genetics study of adolescent depression. Acta Psychol. Sin. 44, 1329-1338.

Howard, D. M., Adams, M. J., Clarke, T.-K., Hafferty, J. D., Gibson, J., Shirali, M., et al. (2019). Genome-wide meta-analysis of depression identifies 102 independent variants and highlights the importance of the prefrontal brain regions. Nat. Neurosci. 22, 343-352. doi: 10.1038/s41593-018-0326-7

Hyde, J. S., and Mezulis, A. H. (2020). Gender differences in depression: biological, affective, cognitive, and sociocultural factors. Harv. Rev. Psychiatry 28, 4-13. doi: $10.1097 / \mathrm{hrp} .0000000000000230$

Iurescia, S., Seripa, D., and Rinaldi, M. (2016). Role of the 5-HTTLPR and SNP promoter polymorphisms on serotonin transporter gene expression: a closer look at genetic architecture and in vitro functional studies of common and uncommon allelic variants. Mol. Neurobiol. 53, 5510-5526. doi: 10.1007/ s12035-015-9409-6

Jacobson, K. C., and Rowe, D. C. (1999). Genetic and environmental influences on the relationships between family connectedness, school connectedness, and adolescent depressed mood: sex differences. Dev. Psychol. 35, 926-939.

Jansson, M., Gatz, M., Berg, S., Johansson, B., Malmberg, B., McClearn, G. E., et al. (2004). Gender differences in heritability of depressive symptoms in the elderly. Psychol. Med. 34, 471-479. doi: 10.1037/0012-1649.35.4.926

Jansson, M., Gatz, M., Berg, S., Johansson, B., Malmberg, B., McClearn, G. E., et al. (2004). Gender differences in heritability of depressive symptoms in the elderly. Psychol. Med. 34, 471-479. doi: 10.1017/s0033291703001375

Keller, M. C. (2014). Gene $\times$ environment interaction studies have not properly controlled for potential confounders: the problem and the (simple) solution. Biol. Psychiatry 75, 18-24. doi: 10.1016/j.biopsych.2013.09.006

Kessler, R. C. (2003). Epidemiology of women and depression. J. Affect. Disord. 74, 5-13. doi: 10.1016/s0165-0327(02)00426-3

Kiely, K. M., Brady, B., and Byles, J. (2019). Gender, mental health and ageing. Maturitas 129, 76-84. doi: 10.1016/j.maturitas.2019.09.004

Krishnan, V., and Nestler, E. J. (2008). The molecular neurobiology of depression. Nature 455, 894-902. doi: 10.1038/nature07455

Ksinan, A. J., and Vazsonyi, A. T. (2019). Genetic and environmental effects on the development of depressive symptoms from adolescence to adulthood in a nationally representative sample. J. Affect. Disord. 245, 163-173. doi: 10.1016/j. jad.2018.10.085

Kuehner, C. (2017). Why is depression more common among women than among men? Lancet Psychiatry 4, 146-158. doi: 10.1016/S2215-0366(16)30263-2

Kulikov, A. V., Gainetdinov, R. R., Ponimaskin, E., Kalueff, A. V., Naumenko, V. S., and Popova, N. K. (2018). Interplay between the key proteins of serotonin system in SSRI antidepressants efficacy. Expert Opin. Ther. Targets 22, 319-330. doi: $10.1080 / 14728222.2018 .1452912$

Lau, J. Y. F., and Eley, T. C. (2006). Changes in genetic and environmental influences on depressive symptoms across adolescence and young adulthood. Br. J. Psychiatry 189, 422-427. doi: 10.1192/bjp.bp.105.018721
Li, J. J., Berk, M. S., and Lee, S. S. (2013). Differential susceptibility in longitudinal models of gene-environment interaction for adolescent depression. Dev. Psychopathol. 25, 991-1003. doi: 10.1017/S0954579413000321

Maciej, T., Divya, M., J, P. W., David, H., Daniel, D., M, H. D., et al. (2019). Quantifying between-cohort and between-sex genetic heterogeneity in major depressive disorder. Am. J. Med. Genet. B Neuropsychiatr. Genet. 180, 439-447.

Maller, J. J., Broadhouse, K., Rush, A. J., Gordon, E., Koslow, S., and Grieve, S. M. (2018). Increased hippocampal tail volume predicts depression status and remission to anti-depressant medications in major depression. Mol. Psychiatry 23, 1737-1744. doi: 10.1038/mp.2017. 224

Maul, S., Giegling, I., Fabbri, C., Corponi, F., Serretti, A., and Rujescu, D. (2020). Genetics of resilience: implications from genome-wide association studies and candidate genes of the stress response system in posttraumatic stress disorder and depression. Am. J. Med. Genet. B Neuropsychiatr. Genet. 183, 77-94. doi: 10.1002/ajmg.b. 32763

McCaffery, J. M., Papandonatos, G. D., Stanton, C., Lloyd-Richardson, E. E., and Niaura, R. (2008). Depressive symptoms and cigarette smoking in twins from the National Longitudinal Study of Adolescent Health. Health Psychol. 27, S207-S215.

McQuaid, R. J., Gabrys, R. L., McInnis, O. A., Anisman, H., and Matheson, K. (2019). Understanding the relation between early-life adversity and depression symptoms: the moderating role of sex and an interleukin-1 $\beta$ gene variant. Front. Psychiatry 10:151. doi: 10.3389/fpsyt.2019.00151

Memon, N. H., Fan, M., Lin, J., Si, Y. J., Su, M., Guo, Q. W., et al. (2018). Reduced recovery of depression in female $\mathrm{T}$ allele carriers of rs1061622 at earlier stage after Wenchuan earthquake. Int. J. Environ. Res. Public Health 15:1075. doi: 10.3390/ijerph15061075

Ming, Q.-s., Zhang, Y., Chai, Q.-1., Chen, H.-y., Hou, C.-j., Wang, M.-c., et al. (2013). Interaction between a serotonin transporter gene promoter region polymorphism and stress predicts depressive symptoms in Chinese adolescents: a multi-wave longitudinal study. BMC Psychiatry 13:142. doi: 10.1186/1471244X-13-142

Möller, I. R., Slivacka, M., Nielsen, A. K., Rasmussen, S. G. F., Gether, U., Loland, C. J., et al. (2019). Conformational dynamics of the human serotonin transporter during substrate and drug binding. Nat. Commun. 10:1687. doi: 10.1038/s41467-019-09675-z

Nivard, M. G., Dolan, C. V., Kendler, K. S., Kan, K. J., Willemsen, G., van Beijsterveldt, C. E. M., et al. (2015). Stability in symptoms of anxiety and depression as a function of genotype and environment: a longitudinal twin study from ages 3 to 63 years. Psychol. Med. 45, 1039-1049. doi: 10.1017/ S003329171400213X

Nyman, E. S., Sulkava, S., Soronen, P., Miettunen, J., Loukola, A., Leppä, V., et al. (2011). Interaction of early environment, gender and genes of monoamine neurotransmission in the aetiology of depression in a large population-based finnish birth cohort. BMJ Open 1:e000087. doi: 10.1136/bmjopen-2011-00 0087

Otte, C., Gold, S. M., Penninx, B. W., Pariante, C. M., Etkin, A., Fava, M., et al. (2016). Major depressive disorder. Nat. Rev. Dis. Primers 2:16065. doi: 10.1038/ nrdp. 2016.65

Patten, S. B., Williams, J. V. A., Lavorato, D. H., Wang, J. L., Bulloch, A. G. M., and Sajobi, T. (2016). The association between major depression prevalence and sex becomes weaker with age. Soc. Psychiatry Psychiatr. Epidemiol. 51, 203-210. doi: $10.1007 / \mathrm{s} 00127-015-1166-3$

Piccinelli, M., and Wilkinson, G. (2000). Gender differences in depression. Critical review. Br. J. Psychiatry 177, 486-492. doi: 10.1192/bjp.177.6.486

Piepenburg, S. M., Faller, H., Störk, S., Ertl, G., and Angermann, C. E. (2019). Symptom patterns and clinical outcomes in women versus men with systolic heart failure and depression. Clin. Res. Cardiol. 108, 244-253. doi: 10.1007/ s00392-018-1348-6

Powers, A., Almli, L., Smith, A., Lori, A., Leveille, J., Ressler, K. J., et al. (2016). A genome-wide association study of emotion dysregulation: evidence for interleukin 2 receptor alpha. J. Psychiatr. Res. 83, 195-202. doi: 10.1016/j. jpsychires.2016.09.006

Priess-Groben, H. A., and Hyde, J. S. (2013). 5-HTTLPR X stress in adolescent depression: moderation by MAOA and gender. J. Abnorm. Child Psychol. 41, 281-294. doi: 10.1007/s10802-012-9672-1 
Ren, X., Yu, S., Dong, W., Yin, P., Xu, X., and Zhou, M. (2020). Burden of depression in China, 1990-2017: findings from the global burden of disease study 2017. J. Affect. Disord. 268, 95-101. doi: 10.1016/j.jad.2020.03.011

Rice, F., Harold, G. T., and Thapar, A. (2002). Assessing the effects of age, sex and shared environment on the genetic aetiology of depression in childhood and adolescence. J. Child Psychol. Psychiatry 43, 1039-1051. doi: 10.1111/14697610.00231

Risch, N., Herrell, R., Lehner, T., Liang, K.-Y., Eaves, L., Hoh, J., et al. (2009). Interaction between the serotonin transporter gene (5-HTTLPR), stressful life events, and risk of depression: a meta-analysis. JAMA 301, 2462-2471. doi: 10.1001/jama.2009.878

Roy, A., Laas, K., Kurrikoff, T., Reif, A., Veidebaum, T., Lesch, K.-P., et al. (2018). Family environment interacts with CRHR1 rs17689918 to predict mental health and behavioral outcomes. Prog. Neuropsychopharmacol. Biol. Psychiatry 86, 45-51. doi: 10.1016/j.pnpbp.2018.05.004

Schumann, L., Boivin, M., Paquin, S., Lacourse, E., Brendgen, M., Vitaro, F., et al. (2017). Persistence and innovation effects in genetic and environmental factors in negative emotionality during infancy: a twin study. PLoS One 12:e0176601. doi: 10.1371/journal.pone.0176601

Scourfield, J., Rice, F., Thapar, A., Harold, G. T., Martin, N., and McGuffin, P. (2003). Depressive symptoms in children and adolescents: changing aetiological influences with development. J. Child Psychol. Psychiatry 44, 968-976. doi: 10.1111/1469-7610.00181

Sjöberg, R. L., Nilsson, K. W., Nordquist, N., Ohrvik, J., Leppert, J., Lindström, L., et al. (2006). Development of depression: sex and the interaction between environment and a promoter polymorphism of the serotonin transporter gene. Int. J. Neuropsychopharmacol. 9, 443-449. doi: 10.1017/s1461145705005936

Spinelli, S., Schwandt, M. L., Lindell, S. G., Heilig, M., Suomi, S. J., Higley, J. D., et al. (2012). The serotonin transporter gene linked polymorphic region is associated with the behavioral response to repeated stress exposure in infant rhesus macaques. Dev. Psychopathol. 24, 157-165. doi: 10.1017/S0954579411000745

Su, M., Cao, T., Feng, Y., Guo, Q. W., Fan, M., and Fang, D. Z. (2017). Longitudinal changes of associations between the preproghrelin Leu72Met polymorphism with depression in Chinese Han adolescents after the Wenchuan earthquake. Psychiatr. Genet. 27, 161-168. doi: 10.1097/YPG.0000000000000180

Sullivan, P. F., Neale, M. C., and Kendler, K. S. (2000). Genetic epidemiology of major depression: review and meta-analysis. Am. J. Psychiatry 157, 1552-1562. doi: 10.1176/appi.ajp.157.10.1552

Trzaskowski, M., Mehta, D., Peyrot, W. J., Hawkes, D., Davies, D., Howard, D. M., et al. (2019). Quantifying between-cohort and between-sex genetic heterogeneity in major depressive disorder. Am. J. Med. Genet. B Neuropsychiatr. Genet. 180, 439-447. doi: 10.1002/ajmg.b.32713

Uddin, M., de los Santos, R., Bakshis, E., Cheng, C., and Aiello, A. E. (2011). Building conditions, 5-HTTLPR genotype, and depressive symptoms in adolescent males and females. J. Adolesc. Health 49, 379-385. doi: 10.1016/j. jadohealth.2011.01.013
Uddin, M., Koenen, K. C., de Los Santos, R., Bakshis, E., Aiello, A. E., and Galea, S. (2010). Gender differences in the genetic and environmental determinants of adolescent depression. Depress. Anxiety 27, 658-666. doi: 10.1002/da. 20692

Van de Velde, S., Bracke, P., and Levecque, K. (2010). Gender differences in depression in 23 European countries. Cross-national variation in the gender gap in depression. Soc. Sci. Med. 71, 305-313. doi: 10.1016/j.socscimed.2010. 03.035

Vaske, J., Makarios, M., Boisvert, D., Beaver, K. M., and Wright, J. P. (2009). The interaction of DRD2 and violent victimization on depression: an analysis by gender and race. J. Affect. Disord. 112, 120-125. doi: 10.1016/j.jad.2008. 03.027

Vijayendran, M., Cutrona, C., Beach, S. R. H., Brody, G. H., Russell, D., and Philibert, R. A. (2012). The relationship of the serotonin transporter (SLC6A4) extra long variant to gene expression in an African American sample. Am. J. Med. Genet. B Neuropsychiatr. Genet. 159B, 611-612. doi: 10.1002/ajmg.b. 32054

Wang, L., Shi, C., Zhang, K., and Xu, Q. (2014). The gender-specific association of EHD3 polymorphisms with major depressive disorder. Neurosci. Lett. 567, 11-14. doi: 10.1016/j.neulet.2014.02.055

Wang, P., Li, B., Fan, J., Zhang, K., Yang, W., Ren, B., et al. (2019). Additive antidepressant-like effects of fasting with $\beta$-estradiol in mice. J. Cell. Mol. Med. 23, 5508-5517. doi: 10.1111/jcmm.14434

Wang, Q., Zhu, X. C., Liu, H., Ran, M. S., and Fang, D. Z. (2015). A longitudinal study of the association of adiponectin gene rs1501299 with depression in Chinese Han adolescents after Wenchuan earthquake. J. Affect. Disord. 175, 86-91. doi: 10.1016/j.jad.2014.12.056

Yancu, C. N. (2011). Gender differences in affective suffering among racial/ethnically diverse, community-dwelling elders. Ethn. Health 16, 167-184. doi: 10.1080/13557858.2010.547249

Young, M. A., Fogg, L. F., Scheftner, W. A., Keller, M. B., and Fawcett, J. A. (1990). Sex differences in the lifetime prevalence of depression: does varying the diagnostic criteria reduce the female/male ratio? J. Affect. Disord. 18, 187-192. doi: 10.1016/0165-0327(90)90035-7

Conflict of Interest: The authors declare that the research was conducted in the absence of any commercial or financial relationships that could be construed as a potential conflict of interest.

Copyright (c) 2020 Zhao, Han, Zhao, Jin, Ge, Yang, Cui, Xu and Li. This is an open-access article distributed under the terms of the Creative Commons Attribution License (CC BY). The use, distribution or reproduction in other forums is permitted, provided the original author(s) and the copyright owner(s) are credited and that the original publication in this journal is cited, in accordance with accepted academic practice. No use, distribution or reproduction is permitted which does not comply with these terms. 